\section{The breathtakingly simple facts of life}

\author{
John Launer
}

How much oxygen do you consume in a day? If you do the arithmetic (proportion of air extracted as oxygen, times tidal volume, times respiratory rate, times minutes per day) it comes to around 500 litres per day. We are largely unaware that we consume so much gas, probably because we cannot see or feel it, just as fish presumably cannot see or feel water. We are of course far more aware of how much food we consume, because we can detect it with every one of our senses. It totals around 600 grams per day for the average healthy person. These gaseous and solid fuels enter our bodies by different and parallel tubes, but they end up interacting with each other in the same way as in any other internal combustion engine, with the release of energy and production of waste products along the way. We may use the citric acid cycle in our cells rather than cylinders, but the principle is the same.

Essentially, the purpose of all this energy is self-replication. Living forms first evolved from inanimate objects probably through chemical reactions in rocks ${ }^{1}$ - in order to manufacture replicas or near-replicas of themselves. Everything that they (and we) have done ever since has been directed towards the same result. Genes use energy to reproduce genes, cells use it to manufacture other cells, organisms use it to perpetuate their own kind, and families or groups use it to look after each other. We are in effect internal combustion engines dedicated to the production of identical or similar ones. This is self-evident, but also somewhat alien to our everyday thinking, even as doctors. Most of us never feel subjectively that our own lives are driven by such very basic principles. An orthopaedic surgeon who is replacing someone's hip on the operating table, for example, is unlikely to be thinking about the oxidation of carbohydrates, proteins and fats or the preservation of kinship groups, let alone how the two

Correspondence to: Dr John Launer, Faculty Development, Health Education England, Stewart House, 32 Russell Square, London WC1B 5DN, UK: john.launer@nwl.hee.nhs.uk processes are linked. If we do try to think in this way, we may suffer the kind of existential discomfort that leads some religious believers to dismiss these ideas as the work of the devil. Even without this denial, we may still feel that these facts, and the connection between them, are of no practical use in the day-to-day pursuit of medical work.

\section{BIOLOGICAL VIEW}

Such a view would be wrong. A remarkable consensus has now emerged in biology that the living world can effectively be understood in exactly these terms, and that there is much to be gained by doing so. According to this point of view, our lives basically involve trying to apply energy from oxidation in the most efficient way possible, for the purpose of producing or supporting progeny and near kin. In the words of biologist Bobbi Low: 'All living organisms have evolved to seek and use resources to enhance their reproductive success. They strive for matings, invest in children or help other genetic relatives, and build genetically profitable relationships. In biology, this is not a controversial proposition, and it follows that organisms will act as though they are able to calculate costs and benefits. $^{2}$

Broken down into its constituent parts, this makes a lot of sense. All of our activities - procreation, raising children, making homes, building communities, forming alliances and fighting with enemies - can be seen as different contributions to the same simple purpose that living organisms have pursued since life first started. A whole range of disciplines from psychology to anthropology are now using this approach to make sense of the world around us. ${ }^{3}$ Social scientists are applying it to look at how societies choose different forms of child-rearing, or relationships between the sexes, in order to adjust to the scarcity or abundance of resources around them. ${ }^{4}$ Neuroscientists are using it to examine how emotions operate. They now see these as our best way - indeed our only way - of assessing our interactions with others and the environment, and of judging how far these are progressing our direct and indirect reproductive interests. ${ }^{5}$ Thus desire, affection, anxiety, envy and rage may each signal perceptions of opportunity or threat, and lead to different ways of investing energy. On this basis, you can understand all the choices we make in our everyday lives as pragmatic calculations, at either a conscious or unconscious level, about what we should do in order to bring about the best prospects for ourselves, our kin and our group.

Such a unified biological view does not depend on seeing the world as purely competitive. It can also help us to understand why people support the interests of their family or group collaboratively, through such things as philanthropy, culture, art, religion and law. ${ }^{6}$ Nor is such a view deterministic. It offers an overarching, 'distal' explanation for human behaviour, but this does not exclude more 'proximate' ways of understanding the world, ranging from molecular explanations to political ones. ${ }^{7}$ Each of these different levels of understanding can add layers of description or meaning to the others. However, when all is said and done, the basis of life remains the same. In scientific terms, it comes down to the regulation of replication, by means of respiration. The facts of life are, indeed, breathtakingly simple.

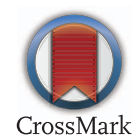

To cite Launer J. Postgrad Med J 2014;90:732.

Postgrad Med J 2014;90:732.

doi:10.1136/postgradmedj-2014-133117

\section{REFERENCES}

1 Lane N, Martin F. The origin of membrane bioenergenetics. Cell 2012;151:1406-16.

2 Low BS. Why sex matters: a Darwinian look at human behavior. Princeton, NJ: Princeton University Press, 2001.

3 Chisholm J. Death, hope and sex: steps to an evolutionary ecology of mind and morality. Cambridge: Cambridge University Press, 1999.

4 Simpson J, Belsky J. Attachment theory within a modern evolutionary framework. In: Handbook of attachment: theory, research, and clinical applications, 2nd edn, Cassidy J, Shaver P. R, ed. New York, NY: Guilford Press, 2008, pp. 131-57.

5 Damasio A. Descartes' error: emotion, reason and the human brain. New York, NY: Putnam, 1994.

6 Nowak R. Supercooperators: Evolution, altruism and human behaviour. London: Canongate, 2011.

7 Laland K, Brown G. Sense and nonsense: evolutionary perspectives on human behavior, 2nd edn. Oxford, Oxford University Press, 2011. 